\title{
Leavings or Legacies? The Role of Early Medieval Saints in English Church Dedications beyond the Conquest and the Reformation
}

\author{
Michael Hicks
}

Every English church is dedicated to some aspect of the godhead or to a patron saint, often commemorated in the place names, such as St Albans in Hertfordshire, Bury St Edmunds in Suffolk, and St Osyth in Essex. Many of the earliest missionaries and those princesses who founded nunneries have been reviewed by Barbara Yorke in work which has done much to reveal the early medieval legacy of the landscape of Britain. ${ }^{1}$ The dedications of parish churches are among the most obvious elements of that legacy but they also reveal much of the perceptions of that legacy in the later Middle Ages.

Although this paper focuses on Anglo-Saxon dedications before the Norman Conquest, the discussion also includes native British saints or Celtic dating before the arrival of the Anglo-Saxons, some of later date, Anglo-Saxon saints who operated within England and abroad (e.g. St Boniface), universal and Roman saints venerated within England, and some others, notably the 11th- and 12th-century Vikings King Olaf Haraldsson and Earl Magnus. This paper considers these early contributions to the pool of dedications current in today's churches and how and why the dedications have multiplied and then were curtailed in the millennium since the Norman Conquest. Thus St Petroc was the most popular native/British or Celtic saint in the West Country, to judge from his fourteen dedications in Cornwall and Devon; there was another church of St Petroc at Winchester. ${ }^{2}$ A much venerated Anglo-Saxon saint was St Botulph (Abbot Botwulf of Iken, Suffolk, c.610-70), who is still commemorated at over seventy locations, most notably the Boston stump in Lincolnshire, St Botolph's Priory in Colchester (Essex), the parish church at Botolphs in Sussex, and the four London parish churches of St Botulph Aldgate, Aldersgate,

1 Barbara Yorke, Nunneries and the Anglo-Saxon Royal Houses (London, 2003); The Conversion of Britain: Religion, Politics and Society in Britain c.6oo-80o (Harlow, 2006); more recently, "Churches and the Christianisation of Early Medieval Britain," in Places of Worship in Britain and Ireland, 300-95o, ed. Paul S. Barnwell (Donington, 2015), pp. 1-30.

2 Nicholas Orme, English Church Dedications with a Survey of Cornwall and Devon (Exeter, 1996), Fig. 1. 
Billingsgate and Bishopsgate. In the final category are the four London churches of St Olave in Bread Street, Hart Street, Old Jewry, and Silver Street that celebrated the Norwegian king Olaf Haraldsson, slain in 1030 at the battle of Stiklestad; St Olave also occurs as a dedication at Chichester, Exeter and at York, where the church was founded by Siward, the Scandanavian earl of Northumbria, prior to his interment there in $1055 .{ }^{3}$ Botulph, Edmund, Swithun, and Wilfrid proved particularly popular, but some dedications occur only once, 88 such examples being in Cornwall. ${ }^{4}$ There was only one known Anglo-Saxon dedication in Cornwall, to SS Cuthbert and Oswald, that can be dated before 800 . St Swithun was an entirely Southumbrian saint. ${ }^{5}$ Dozens, scores, even perhaps hundreds of Anglo-Saxon churches were dedicated to such native saints before the Norman Conquest, yet are hidden from historians because they feature in no writings and nothing identifiably Anglo-Saxon survives of their buildings. However early they are, such dedications are normally first recorded after the Norman Conquest, when indeed the parishes may have been defined and the churches built. It is these post-Conquest medieval dedications to preConquest native saints that are the subject of this paper.

It is striking that relatively few of the 9,00o English parishes founded before 1200 have distinctively Anglo-Saxon and Celtic dedications. Very many were founded by the Anglo-Saxons, perhaps the vast majority of English medieval parish churches, but the founders of such local churches normally chose their patrons not from native saints, but rather from scripture and late antiquity, from the apostles (e.g. St Andrew), evangelists (e.g. St Matthew), early Roman martyrs and especially virgin martyrs (St Margaret of Antioch), the Archangel Michael, popes (St Clement and St Gregory), bishops and abbots (Martin of Tours), and from semi-legendary and still half-remembered saints like St Christopher and St George. ${ }^{6}$ This devotion to 'universal saints' was a triumph of the Roman mission of St Augustine over the Celtic church of St Aidan. Apparently the Anglo-Saxons replaced earlier dedications and place names as they colonised the 'Celtic fringe,' Cornwall and Cumbria. ${ }^{7}$ Their dedications have

3 See papers by Robert Higham, "The Godwins, Towns And Churches: Comital Investment in the Mid-11th Century," above, and Karl Alvestad, "Olavian Traces in Post-Medieval England," below.

4 Orme, Dedications, p. 133 .

5 Michael Lapidge, The Cult of St Swithun, Winchester Studies 4.2 (Oxford, 2003), p. 47.

6 Orme, Dedications, p. 17; Lapidge, Cult of St Swithun, p. 47.

7 Yorke, Conversion, pp. 189-92; Orme, Dedications, p. 9. Celtic dedications were also common for chapels, often apparently post-Conquest: Nicholas Orme, "Church and Chapel in Medieval England," TRHS 6th ser., 6 (1996), 75-102, at p. 81; "The Other Parish Churches: Chapels in 
generally endured until the present day. That they are Anglo-Saxon choices is seldom recognized.

\section{The Meaning of the Dedication}

Dedications of churches are the raw material for this paper. Establishing dedications is not straightforward. If every church now has a particular patron, this can seldom be proved always to have been the case. The first date when a dedication is recorded is usually centuries after the particular church was founded or to which the earliest architectural fragment can be attributed. Dedications in Cornwall and Devon are often documented only from the mid-18th century. Medieval records of ecclesiastical administration or royal patronage concerned themselves with the church as benefice, as a source of taxation, as a structure to be built and maintained, identifiable by its location, rather than by its dedication, however liturgically important that may have been. Reading back from the known to the unknown, may be a doubtful procedure, but is unavoidable and it is a well-founded practice of reputable historians. ${ }^{8}$

Dedications had a meaning. The saint had done something, suffered somehow, or had been martyred which qualified him/her to be a saint and to be revered. St Augustine brought with him a sheaf of Roman saints and especially virgin martyrs who became patrons of many Anglo-Saxon churches in the centuries that followed. Local confessors achieved sainthood from the 6th century, perhaps usually acknowledged at the particular church that they founded or wherein they were interred. Their appeal was always limited, especially geographically: they were West County, Northumbrian, or East Anglian saints. Most churches were dedicated by the 9 th and 1oth centuries, when their cults expanded beyond their home localities. St Cuthbert and St Wilfrid apart, few had vitae before the 11th century, and many had none. The Normans inherited the shrines and dedications of saints whose names and saints days encompassed almost everything that was known. ${ }^{9}$

Very few dedications can be dated precisely. Obviously they cannot be earlier than what is commemorated. When rulers or archbishops were martyred, there are dates after which dedications in memory must belong: after 642 for

Late Medieval England," in The Parish in Late Medieval England, ed. Clive Burgess and Eamon Duffy (Donington, 2006), pp. 78-94, at p. 85; see also below, pp. 591-94.

8 Orme, Dedications, p. 19; W. Urry, Canterbury under the Angevin Kings (London, 1967), pp. 207-08; Derek Keene, Survey of Medieval Winchester, Winchester Studies 2 (Oxford, 1985), 1:107; Lapidge, Cult of St Swithun, p. 43.

9 Yorke, Nunneries, pp. 17 and 20; Conversion, pp. 172 and 189-92. 
King Oswald, 869 for King Edmund, after 882 for Bishop Swithun, 978 for King Edward, 1012 for Archbishop Alphege, 1030 for King Olaf, c.1116 for Magnus Earl of Orkney, and 1170 for Archbishop Thomas Becket. The Empress Helen, Abbot Martin of Tours, and St Pancras all 'seem' early. "The church of St Mildred at Canterbury" that already existed by 1084, Urry surmised, was "probably not established by a Norman."10 Later, the date of official canonisation becomes critical.

Theoretically these cults went out of date. Was anybody really interested in King Olaf after the Norman Conquest? Contemporaries, it appeared, admired St Botolph, but what was it that he represented five centuries after his death when selected again? What did late founders who selected much earlier saints know about them? And who chose the dedication anyway - a lay founder or a priest? Dedications ought to be revealing about what was admired and was fashionable (thus appealing beyond a particular group and/or locality at a particular time). What aspect of the cult endured? This in turn ought to admit historians to the mores, social values, and intellectual environment of the later era.

The English parish system was virtually complete by 1200 . New churches continued to be founded, but their status was not of parish churches, but rather of chapels within parishes. Great churches in newer towns, such as Holy Trinity at Hull, St Mary Beverley, and St Mary Redcliffe in Bristol remained in status mere chapels. Parish churches often originated earlier than the documentary record for them. Many early churches that were probably small and constructed of wood were totally obliterated when rebuilt in stone and were repeatedly refashioned to create today's predominantly Gothic structures that rarely preserve visible traces of their Saxon origins. Some occur in earlier records like the eight churches at York mentioned at the time of Domesday Book. ${ }^{11}$ Almost all therefore antedate the earliest surviving fabric by several centuries. The first evidence for a dedication is also usually late, after the emergence of relevant records and therefore post-120o, but dedication itself though unrecorded was normal from the 4 th century, consecration by a bishop mandatory from the $5^{\text {th }}$ century, and was ultimately invariable. Almost all medieval parish churches were rebuilt or extended several times, yet retained their dedications. That is why the predominantly 13th- and 14th-century churches of Romney Marsh at Brookland, Brenzett and Snargate are still dedicated to Augustine and Dunstan, both early archbishops, and even to Eanswith, the Anglo-Saxon virgin. That the churches and dedications precede 1200 is one

\footnotetext{
10 Urry, Canterbury, p. 208.

11 VCH Yorks.: City of York, 1, p. 361.
} 
reason why post-Conquest saints became patrons of very few parishes. The great exception was Thomas Becket (Thomas the Martyr, d.1170, canonised 1173), a genuinely national saint whose patronage was adopted at existing churches at Portsmouth (now Portsmouth Cathedral) and Fairfield in Romney Marsh, at South Cadbury church and chapel in Somerset, by altars in the city and minster of York, and often in votive masses. ${ }^{12}$ The dedication to him of Box church in Wiltshire, which already existed in 1159, must therefore be a renaming. Maybe Box, like the other four daughters of St Andrew's (minster) church at Chippenham, was originally dedicated to St Nicholas..$^{13}$ The Victoria County Histories systematically record all churches and their dedications, but do not automatically note the earliest date when the dedication occurs. Reading all dedications back from their first occurrences in the records, usually 13th- or 14th-century, to the foundation of the church, is justifiable, but dedications sometimes changed. The Anglo-Saxons sometimes substituted their own choices for Celtic saints and similarly the Normans probably replaced AngloSaxon dedications. ${ }^{14}$ Hence perhaps the coupling of the Virgin or apostles with native saints that originally stood alone. ${ }^{15}$ Henry vin's hostility to St Thomas Becket, the Canterbury martyr, whose veneration he banned, resulted in many churches being re-attributed to St Thomas the Apostle (Doubting Thomas), hitherto not particularly popular, for example at Cowick (Devon). ${ }^{16}$

Some light on these issues emerges from Lapidge's investigation of a popular Anglo-Saxon saint, Bishop Swithun, who died in 863. Winchester Cathedral, originally dedicated to the apostles Peter and Paul, then additionally to Holy Trinity and St Swithun, eventually and colloquially was dedicated to Swithun only: a guide, as Lapidge says, to the development of the cult. Although the only other church of St Swithun to be firmly dated to the mid-12th century is at Abingdon and thereafter Woodbury in Devon to 1205 and St Swithun's

$12 V C H$ Somerset 9, pp. 105 and 107; VCH Yorks: City of York, pp. 369 and 374; Fabric Rolls of. York Minster, ed. J. Raine, Surtees Society 35 (1858), p. 206; William Dugdale, Monasticon Anglicanum, 8 vols (London, 1846), 2:57.

13 English Episcopal Acta, 18: Salisbury, 1078-1217 (Oxford, 1999), no. 18.

14 Ridyard rejects "the myth of Norman scepticism" towards Anglo-Saxon saints. Susan Ridyard, "Condigna veneratio: Post-Conquest Attitudes to the Saints of the Anglo-Saxons," ANS 9 (1986), 179-206 (quotation at p. 204); see also R.W. Pfaff, "Lanfranc's Supposed Purge of the Anglo-Saxon Calendar," in his Liturgical Calendars, Saints and Services in Medieval England (Aldershot, 1998), pp. 96-108. Dedication evidence suggests otherwise; see Rebecca Browett, "The Fate of Anglo-Saxon Saints After the Norman Conquest of England: St Æthelwold of Winchester as a Case Study," History 101 (2016), 183-200.

15 E.g. St Egwin (Evesham), St Pandonia (Eltisley, Norf.), St Sexburga (Minster in Sheppey). But see also below p. 587 .

16 Orme, Dedications, p. 42. 
Kingsgate in Winchester to 1264, all or most of the 68 parish churches of St Swithun were surely dedicated to him by the 12th century onwards. Lapidge's caution is justified because parishes ceased to be created after 1200 and indeed often the surviving fabric of St Swithun's churches are earlier. Of six churches of St Swithun on the estate of Winchester cathedral priory, ${ }^{17}$ Nately Scures (Hants) possesses "a complete miniature Norman church" of $c .1130-40$, Martyr Worthy a nave of $c .1140$, Little Hinton (Wilts.), a 12th-century arcade, and Headbourne Worthy (Hants), a large Late Saxon church. ${ }^{18}$ What do physical remains of other such churches reveal? It is beyond the scope of this paper to consider how dedication evidence could indicate the development of the Anglo-Saxon Church. Swithun dedications therefore began before the Conquest, continued thereafter and apparently stopped only when new parishes ceased to be created.

Frances Arnold-Foster estimated that in England there were over two thousand medieval dedications to the Virgin Mary, half that number to All Saints, hundreds to St Peter and St Paul, St Andrew, St Nicholas, St Lawrence, St Catherine and St Margaret, and significant numbers to the other apostles, Roman martys and virgin martyrs. ${ }^{19}$ Those parish churches dedicated to native saints from before the Norman Conquest were therefore always very few. After the conquest there were almost no new dedications to St Botolph, the Norwegian St Olaf, or the south-western saint St Nectan. Celtic influence makes Cornwall and Devon exceptional, but dedications here are also best recorded and evidence from them must be used. The 700 medieval dedications of Cornwall and Devon fell eventually fell into three categories: the scriptural and west European tradition; Cornish saints, sometimes identified, who often occurred only once; and a tiny minority, perhaps only a score, of Anglo-Saxon saints. Cuthbert, Edmund, Edward, Olaf and Swithun occur in single figures. ${ }^{20}$ Only in the most English major cities with many parishes where churches needed to be distinguished by name did a few receive pre-Conquest dedications.

London had more parish churches than any other city-about 120 in the mid-11th century - and had more with Anglo-Saxon dedications than anywhere else. Their foundations and dedications cannot be substantiated significantly earlier in time. "Little is known about the formation of these parishes and the building of the great majority of the churches of London," wrote Joyce

\footnotetext{
17 Lapidge, St Swithun, pp. 42-43.

18 Nikolaus Pevsner and Bridget Cherry, Wiltshire, 2nd ed. (London, 1975), pp. 299-300; Michael Bullen, John Crook, Rodney Hubbuck, and Nikolaus Pevsner, Hampshire: Winchester and the North (London, 2010), pp. 320-21, 390 and 403.

19 Frances Arnold-Forster, Studies in Church Dedications, or England's Patron Saints, 3 vols (London, 1899).

20 Orme, Dedications, pp. 37-40.
} 
Jeffries Davis, "but it is certain that by the end of the 12th century, and in all probability much earlier, the parochial boundaries were defined as they remained through the Middle Ages." 21 St Gregory's church can be dated firmly to 1010, St Magnus' church is from the 12th century, thirteen others existed by 1100, another 69 by 1200 , and probably the remaining 28 also predated 1200 . St Peter Cornhill, St Alban Wood Street, and St Andrew Holborn are reputedly very ancient. How many of these were pre-Conquest, let alone from the 1oth, gth, 8th or 7 th centuries is quite unknowable - at least without extensive archaeological investigation. As elsewhere, the parish churches of medieval London were mainly dedicated to the Virgin and other commonly venerated saints, but they did include four dedicated to Botolph, five to Olave, two each to Dunstan and Mildred, and others to Augustine, Edmund the King, Magnus the Martyr, and Swithun. ${ }^{22}$ At best a sixth of London churches therefore were dedicated to preConquest native saints.

The same pattern emerges rather less clearly in the other major towns. There were 46 parish churches at York. The dedications of seven known preConquest parish churches are known. These did include the pre-Conquest Cuthbert and Olaf, but the other five were scriptural, antique, and west European. Amongst the other 39, the one dedication to a native saint, St Edward king and martyr, needs to be set against six to the Virgin, four to All Saints, three each to Holy Trinity, St Helen, St John, and St Michael, and the remainder to other legendary and west European saints. ${ }^{23}$ Among the 54 parish churches at Winchester in 1300, only the foundations of St Andrew and St Gregory (both now lost) can be firmly dated before the Conquest and most are not recorded before the later 11th century, yet, writes Keene, "it is likely that those with parochial status already existed in the mid 12th century and that most of them were founded before 1100." Thirty different patrons are recorded: Our Lady nine times, Martin six times, Peter five times, Michael four times, John thrice, All Saints and Nicholas twice. All are universal saints. The only native dedications were to Alphege (killed in 1012) recorded in 1284, Boniface (1172), Petroc and Swithun (two dedications). ${ }^{24}$ Among the 29 at Exeter, where 17 dedications were in the scriptural/west European tradition, there were eleven that related to earlier native saints - to Cuthbert, to the three royal martyrs Edmund,

21 J. Jeffries Davis, "Ecclesiastical History," in $V C H$ London 1 (London, 1909), p. 179.

22 Jeffries Davis, "Ecclesiastical History," pp. 180-81 and 190.

23 VCH Yorks: City of York, pp. 365-91. St Edward and some of the others could be preConquest dedications.

24 Alexander R. Rumble, Property and Piety in Early Medieval Winchester, Winchester Studies 4.2 (Oxford, 2002), p. 35; Keene, Survey, 1:107 and 134-35. 
Edward and Olaf, and to the four Celts David, Kerrin, Petroc and Sidwell. ${ }^{25}$ The 22 recorded at Canterbury included the surviving churches of St Alphege and St Dunstan, both archbishops, recorded in 1174-75, and St Mildred (1084), but no other pre-Conquest native saints. Over thirty parish churches in Norwich include just three pre-Conquest dedications to SS Botolph, Olave, and Swithun. ${ }^{26}$ The twenty-odd parish churches established at Bristol feature a single pre-Conquest dedication to the Mercian St Werburgh. ${ }^{27}$

It is doubtful quite what such dedications implied. Few of these churches contained relics of their patron saints or shrines and almost none of them became objects of pilgrimage or veneration. Admittedly all saints were assigned their own saints day and at one time all patron saints enjoyed their own annual festival of services focused on themselves. However relatively few festivals were included in the calendars of greater churches even in the Anglo-Saxon era to spread their commemoration beyond their own churches. There were already too many saints, so calendars omitted most recent saints of purely local importance. ${ }^{28}$ By the 13 th century, when the use of Sarum apparently developed, so many saints were crowding the Church's calendar and cutting across the celebration of the liturgical year that drastic cuts were implemented. These particularly devalued native saints. This problem of excessive festivals recurred several times.

First of all, the three uses of Sarum, York and Hereford adopted 'normative' calendars which excluded many pre-Conquest British and Anglo-Saxon saints. There was no room, for instance, for Abbot Botolph or King Olaf, and those retained, such as Archbishop Alphege, Bishops Birinus of Winchester, Mellitus and Erkenwald of London, were not necessarily popular and were indeed seldom selected for parochial dedications. ${ }^{29}$ The adoption of the Sarum Use throughout the province of Canterbury by $c .1375$ caused the dropping from the calendars of such local saints as Egwin, Guthlac, Mildred, Modwenna, Neot,

25 Orme, Dedications, p.35.

26 Ken Farnhill, Guilds and the Parish Community in Late Medieval East Anglia c.1470-1550 (Woodbridge, 2001), pp. 196-97.

27 For the significance of Werburgh dedications elsewhere, see Alan Thacker, "St Wærburh: The Multiple Identities of a Regional Saint," above, pp. 443-66.

28 English Kalendars before AD 1100, ed. Francis Wormald, HBS 72 (London, 1934); Rebecca Rushforth, ed., Saints in English Kalendars before AD 1100, HBS 117 (Woodbridge, 2008).

29 Erkenwald, bishop of London from 675, seems not to have appealed to Londoners. See Eamon Duffy, "St Erkenwald: London's Cathedral Saint and his Legend," in The Medieval English Cathedral, ed. Janet Backhouse (Donington, 2003), pp. 150-67, at p. 152; Alan Thacker, "The Cult of Saints and the Liturgy," in St Paul's: The Cathedral Church of London 604-2004, ed. Derek Keene, R. Arthur Burns and Andrew Saint (London, 2004), pp. 113-22, at pp. 118, 121. 
Osyth, Rumwald, and Werbergha. ${ }^{30}$ SS Grimbald and Edburgh, who remained in the calendar, were not used for dedications. Secondly, many were downgraded in the event of calendar clashes, as the Sarum ordinal prioritised major festivals over minor ones. Inclusion in the calendar did not necessitate a separate set of services in the Sanctorale or even guarantee actual observance. All that most selected saints received, thirdly, was the common services for their particular category of saints-common for bishops, confessors, martyrs, virgins, or virgin martyrs - and a personal memoria at vespers, matins and lauds. Only a few preferred saints qualified for double feasts, which entailed a full complement of proper services specifically devoted to them, with nine lessons and nine responses at matins in secular churches and twelve in monasteries that might extend over the whole octave. A full range of observances was composed for St Swithun, but even his was not a double feast, and not all of his observances therefore featured in the Sarum breviary. Very few so preferred were native: St Cuthbert being an obvious instance. Fourthly, each use amalgamated dedication feasts on a single date, 15 September for Sarum until 1319, when it was moved to 30 September to avoid clashing with the important Nativity of the Blessed Virgin on 9 September, and for York in 1489 to the Sunday after the Commemoration of St Paul (19 January). Henry viII made 1 October into the national dedication day. ${ }^{31} \mathrm{~A}$ single day was also set for the veneration of relics. Such measures should have meant that most pre-Conquest native saints ceased to be celebrated in their own churches even on their own festival days. Some did however: in West Somerset the feast of St Carantoc was celebrated at Carhampton in the mid-13th century and the translation of St Decuman at Watchet in 1412.The cult of St Edburga was still celebrated in mid 15th-century Bicester (Oxon.) ${ }^{32}$ Nevertheless dating by saints days, in letters and inquisitions post mortem, does show that some of these less favoured saints still impinged on writers' memories.

It is only in recent years, the late 2oth and early 21st centuries, that the Church has tackled depopulation and dwindling congregations in the countryside with suspending presentations, uniting benefices into groups, and declaring some churches redundant. Most medieval churches therefore survive. Such problems were addressed sooner in the principal towns of medieval England that were overstocked with under-endowed churches and where

$30 \quad$ Nigel Morgan, "The Sarum Calendar in England in the Fourteenth Century," in Saints and Cults in Medieval England, ed. Susan Powell (Donington, 2017), pp. 5-23, at p. 11.

31 Matthew Cheung Salisbury, The Secular Liturgical Office in Late Medieval England, Medieval Church Studies 36 (Turnhout, 2015), p. 90.

$32 V c H$ Somerset 5 (1985), p. 168; Somerset Heritage Centre DD/L/P/163; DD/WY 9/W2; Morgan, "Sarum Calendar," p. 11. 
many parishes were therefore united. "St Edmund Ridingate at Canterbury did not survive the fourteenth century", wrote Urry, "and others followed."33 The 54 churches of Winchester in 1300 had dwindled to 37 by 1500 and now to a mere six, not all still parochial churches. ${ }^{34}$ Most striking is London, where 85 churches were destroyed in the Great Fire of 1666 and not all were restored, 23 were demolished under the Union of Benefices Act (1860), and most of the survivors were damaged or destroyed in the Blitz in the Second World War. When such churches were lost and their parishes absorbed by others, their dedications disappeared. There is therefore no church honouring Alphege, Boniface or Petroc in Winchester today. If pre-Conquest dedications are commonplace, medieval dedications to Anglo-Saxon saints are few in number, and yet fewer date from the half millennium between the Norman Conquest and the Reformation.

\section{Post-Conquest Dedications}

Because most parish churches were founded before 1200 , it is not to parish churches that we should look for post-Conquest dedications, but to other religious institutions which were much more numerous. Orme estimates that there were another 20,000 chapels of all types, ${ }^{35}$ some pre-Conquest, but the majority later. There came to be some goo monastic houses founded before 1300, more than a thousand hospitals dating from 1100-1540, several thousand chantries, guilds and fraternities established mainly in 1300-1540 in existing structures, and many thousands of new altars within all these new foundations and parish churches, all of which ought to have been consecrated and dedicated by bishops, besides lights, wall paintings, screen panels, sculptures, and vestments also commemorating particular saints. ${ }^{36}$ Originally perhaps churches had only one altar: in $115^{\circ}$ only four of 20 churches in London possessed more than one. ${ }^{37}$ As churches expanded, so altars multiplied, until only the tiniest single-cell church was left with just one. These extra foundations represent successive modes of religious expression and fashions in the objects of devotion. Whilst most of these too were devoted to biblical and traditional western European saints, they did include numerous dedications to native

33 Urry, Canterbury, pp. 208, 210.

34 Keene, Survey, 1:107.

35 Orme, "Other Parish Churches," p. 80.

36 These are specifically excluded from discussion here.

37 VCH London 1, p. 180. 
saints pre- and post-Conquest and to aspects of the Virgin and the Passion that indicate the enthusiasms of particular individuals and groups at particular dates.

Many Benedictine monasteries, secular cathedrals and royal free chapels, and minsters that became Augustinian priories preceded the Norman Conquest and thus perpetuated their dedications. Examples are the dedication to the Holy Trinity at Christchurch (Hants, now Dorset), Cuthbert at Durham, Æthelrelda (Ely), Æthelbert (Hereford), Frideswide (Oxford, 1122), German in Cornwall, Morwenna (Burton on Trent), Sexburga (Minster in Sheppey, Kent), and Wulfhad (Stone, Staffs.). Noting their pre-Conquest patrons, J.H. Denton observed that " $[\mathrm{m}]$ ost of the royal free chapels had been Anglo-Saxon minsters". Admittedly many of the saints had been from the universal list, but they also numbered St Oswald at Gloucester and Harold Godwinson's Waltham Holy Cross (Herts.). The secular college at Wimborne in Dorset remained dedicated to St Cuthberga. ${ }^{38} \mathrm{~A}$ host of Benedictine cells (alien priories), Augustinian, Cistercian, Cluniac, Carthusian, Gilbertine, and Premonstratensian monasteries were founded in the two centuries after the Norman Conquest and friaries from the 13th century onwards. Cistercian houses were generally dedicated to the Virgin and many friaries to St Francis and St Dominic. That the new Norman bishops and abbots disapproved of Anglo-Saxon cults has been questioned, yet the number of new foundations with Anglo-Saxon patrons was actually quite small. A few new examples are St Augustine (at Bristol in 1140 and Wellow in 1132), St Botolph (Colchester, c.110o), St Cuthbert (Carham, Northumberland, 1131), St Edburga (Bicester, Oxon., 1182×5), St Nectan (Hartland, c.1161), St Oswald the King (Nostell, Yorks., 1114), and St Wilfrid (Hornby, Lancs., 12th century; Moberley, Ches., 1206). ${ }^{39}$ Quite often existing patrons like Edwold at Cerne Abbey, Egwin at Evesham Abbey, and Morwenna at Burton Abbey became coupled with or subjected to the Virgin or St Peter. ${ }^{40}$ Hospitals, all post-Conquest foundations, were generally dedicated to scriptural saints, notably SS James and Bartholomew, or to a subgroup of universal saints, such as Anthony, Katherine, Margaret and Nicholas. Very few were dedicated to English saints. Most popular was St Edmund King and Martyr, with two dedications, and St David, also with two: King Æthelbert featured in Hereford (where

38 J.H. Denton, English Royal Free Chapels 1100-1300: A Constitutional Study (Manchester, 1970), p. 23.

39 Alison Binns, Dedications of Monastic Houses in England and Wales 1066-1216 (Woodbridge, 1989), passim. Binns treats only male houses, however.

40 Ibid., p. 65. So too with parish churches: St Pandonia became paired with St John the Baptist at Eltisley; Virginia Bainbridge, Gilds in the Medieval Countryside: Social and Religious Change in Cambridgeshire, c.1350-1558 (Woodbridge, 1996), p. 63. 
the cathedral was dedicated to him), Archbishop Oswald (d. 992) and Bishop Wulfstan (d.1095) at Worcester, and after the Conquest Thomas Becket and Archbishop Edmund Rich. ${ }^{41}$ Nicholas Orme and Margaret Webster's more exhaustive research revealed St German as the only Briton among patron saints in Cornwall and Devon. ${ }^{42}$

Unlike parish churches, most monasteries and hospitals can be dated with precision. Castle chapels also can be bracketed to the two centuries after 1066. Nicholas Orme's reading is useful here: "When castles appeared at the Conquest, they too included chapels for their lords, castellans and retinues. Bristol, Coventry, Dover, Exeter, Hereford, the Tower of London, York, and many others had such amenities, sometimes with permanent staffs of clergy."43 Some of the latter were royal free chapels or secular colleges. H.M. Colvin documents works on chapels at 23 royal castles and another 12 royal residences from 1200 onwards. Some castles had several chapels ranging from those with naves and arcades to timber structures a few yards square or oratories by the door/off the chamber of the king. Of royal castles, Chester had three chapels, Dover at least three, Hadleigh two, Leeds (Kent) at least two, the Tower of London about five, Ludgershall three, Marlborough two, Nottingham three, Oakham two, Winchester at least four. So too palaces and hunting lodges: six at Woodstock. Colvin documents how many of these were conjured up in a particular year by whim of Henry III and subsequently forgotten. ${ }^{44}$ Unfortunately most were unendowed-property generates records and hence evidence of dedicationand most castles went out of use before 1200 or at least 1300 , when records can reasonably be expected to survive. The clergy seldom appear in bishops' registers. "Most castle chapels were simply private altars," wrote Denton. ${ }^{45}$ Mere consecration did not create a record. And the king's accounts rarely refer to the dedication-rather to the king's chapel, the queen's chapel, the great chapel, the new, lesser, lower or upper chapel. At Ludgershall the three chapels were dedicated to St Katherine, St Leonard, and St Nicholas, at Guildford to St Katherine and St Stephen, and at Winchester there were chapels of St Judoc (d. 668, a Breton), ${ }^{46}$ St Katherine and St Thomas Becket.

41 R.M. Clay, Medieval Hospitals of England (London, 1909), pp. 252, 260, and 263-64.

42 If this is the 'right' St German: Nicholas Orme and Margaret Webster, The English Hospital 1070-1570 (New Haven, CT, 1995), p. 192.

43 Orme, "Church and Chapel," p. 76.

44 H.M. Colvin, R.A. Brown and J. Taylor, History of the King's Works. The Middle Ages, 2 (London, 1963), passim.

45 Denton, Chapels, p. 129.

46 Ryan Lavelle kindly pointed out that St Judoc was associated with Kings Æthelstan and Edward; perhaps his dedication may have passed from an Anglo-Saxon palace dedication. 
The sample of known dedications is very small. Some chapels contain multiple altars, like the three at Dover St Andrew dedicated to St Adrian, probably Hadrian, abbot of St Augustine's Abbey at Canterbury, who died in 709, and the definitely pre-Conquest St Edmund and St Edward. Henry III did order numerous images, paintings, and windows relating to the Majesty, to SS Edmund, Edward, Eustace, John the Evangelist, Mary, Thomas and William. Most common was St Edward, probably the Confessor, but at Gillingham in Dorset both Edward the Confessor and Edward King and Martyr were celebrated in glass. King Henry III, for it is usually he, enjoyed planning these chapels, their dedications and decorative schemes. He ranged widely in his choice of edifying iconography for himself, his queen and entourage, particularly regarding Anglo-Saxon royal saints. ${ }^{47}$ There had been hundreds of private castles too, dozens of which lasted enough to include permanent chapel, but for these the source material is even sparser and more difficult to locate.

Castle chapels were included in Orme's chapel category, but other types of chapels were more numerous. There were thousands of chapels of ease or free chapels, scores of chapels on hills, bridges, by the wayside, on hilltops, or near wells, even a couple on battlefields, in caves and in other locations. They held no property, were subjected to no presentations or visitations, and were generally abandoned at the Reformation, so few of their dates of foundation or dedications are known. At Bristol, where seven chapels are recorded, two were dedicated to the Irish saint Brendan and to Jordan are pre-Conquest. ${ }^{48}$

Most of these institutions contained other altars that also had to be consecrated. In honour of St Æthelburga there was the shrine, altar and chantry in Barking Abbey. ${ }^{49}$ Some major foundations contained numerous altarscertainly many more altars than can ever be identified. At Christchurch (Hants, now Dorset) there were certainly nine altars in the east end, the parish altar, others in the crypt and St Michael's loft, and another three cage chantries interpolated into existing spaces, thirteen or perhaps even twenty in all. ${ }^{50}$ Though a parish church now, Christchurch housed an Augustinian priory in the middle ages and shares therefore in the monastic cartulary, but most parishes do not. Parish archives never survive before the mid 14th century, thereafter only rarely, and deal principally with income and expenditure rather than worship. Royal licences to alienate in mortmain, a principal source for

47 Colvin, et al., King's Works, 2, passim.

48 Orme, "Church and Chapel," p. 81.

49 Orme, Dedications, p. 248.

5o Cindy Wood, "The Cage Chantries of Christchurch Priory," in Memory and Commemoration in Medieval England, ed. Caroline Barron and Clive Burgess (Donington, 2010), pp. $234-50$, at p. 237. 
chantry foundation, focused on endowments, not the liturgy, and so did the rarer chantry deeds, but all chantries involved the celebration of mass at an altar designated by the founder and hence dedicated. Hence the dedication of most of the ninety chantries in the 46 parish churches of medieval York are unrecorded. This need not mean that the dedications did not matter, but that liturgical celebrations generated no extant sources. Only 25 of the 46 churches hosted chantries, yet some contained eight, six, four or two. Our Lady was by far the most popular patron, with at least 28 chantries in her honour, with up to three in the same church and same altar; the Apostle James, St John the Baptist, St Katherine, and St Thomas the Martyr lagged well behind. Anglo-Saxon saints do not feature at all. The 15 chantries in St Nicholas's church, Newcastleupon-Tyne (now Newcastle Cathedral) included only one sited at the altar of a pre-Conquest saint, Cuthbert, founded as late as the reign of Richard II. ${ }^{51}$

It was only when there were more altars and chantries in a single location that native saints appear. This situation arises only in the greatest churches that contained multiple altars and chantries. Remember that by the late middle ages all regular clergy were expected to be priests and all priests were expected to celebrate mass daily, which created a demand for altars and hence a wider variety of dedications. By 1200 altars at St Paul's Cathedral included King Oswald, Bishops Cedd of the East Saxons (d. 664) and Chad of Lichfield (d. 672), to which were added in 1247 King Ethelbert, and by the 1260 s Edward the Confessor. ${ }^{52} \mathrm{~A}$ chronicle of Byland Abbey records the consecration of its altars in stages from the east as the church was erected: the high altar (St Saviour) and St Stephen in 1195, in 1214 the nave altar of Holy Trinity and the altars of SS Augustine, Edmund, John the Baptist, Peter and Paul in the transepts, and in 1221 those of SS Michael and Martin. ${ }^{53}$ Of these only SS Augustine and Edmund were Anglo-Saxon saints. There were 66 chantries attached to altars in York Minster. Amongst the usual scriptural saints, virgin martyrs (Agnes, Cecilia, Petronilla) and modern saints (Thomas Becket, William of York), there feature dedications to Gregory the Great, to Bishops Chad, Cuthbert, Paulinus and Wilfrid, to Edmund and Edward kings and martyrs, to the virgin Frideswide, and to Ninian. The altar dedicated to Cuthbert was probably earlier, but the chantry founded there by Bishop Skirlaw dated only from 1405. The altar of St Ninian,

$5^{1} \quad$ Eneas Mackenzie, "St Nicholas' Church: History and Architecture," in Historical Account of Newcastle-Upon-Tyne Including the Borough of Gateshead (Newcastle-upon-Tyne, 1827), pp. $235^{-55}$.

52 Thacker, "Cult of Saints," p. 117.

53 VCH Hants 2 (1903), pp. 153-54, which wrongly locates the narrative at Christchurch (Hants, now Dors.); The Christchurch Priory Cartulary, ed. K.A. Hanna, Hampshire Record Series 18 (2007), p. xxvii. 
the 6th-century apostle to Galloway, may also be very late. First recorded in $1483^{, 54}$ it was perhaps prompted by Richard III, a documented devotee.

Similarly the 30 different altars in St Paul's Cathedral that hosted 84 chantries were dedicated mainly to saints of scripture and antiquity. Only Thomas the Martyr was post-Conquest in date and only Archbishop Dunstan, Bishops Chad and Erkenwald were Anglo-Saxon. New altars were added as the cathedral was upgraded and extended and were located in the old structure, nave, choir and transepts, in the crypt and charnel house, in the new work, and in one case in a cage chapel inserted between the pillars of the arcade. ${ }^{55}$ Wholly new foundations could tailor the buildings to the liturgy. The feasts of the martyred kings Edmund and Edward were upgraded to inferior double feasts at Fotheringhay, where sung mass was ordained in honour of St Winifred virgin and martyr at Halloween, and on midsummer eve another in honour of St Æthelrelda. ${ }^{56}$ The match between such masses and the altars was seldom complete: often indeed chantries moved altars as ordained by the chapter.

Gilds and fraternities were voluntary religious groupings generally operating from parish churches. Some antedated the Norman Conquest like the Thegns' gild in Cambridgeshire that venerated St Æthelrelda of Ely, ${ }^{57}$ but the principal source, the parliamentary survey of 1389 , detailed gilds established within recent memory. Those that were property-owning were recorded in the chantry certificates of $1546-48$, but far more are known only by references in wills. The 64 with extant statutes in Cambridgeshire were Marian, scriptural, or from the western tradition excepting one in honour of St Æthelrelda. She was daughter of Anna, king of East Anglia (d. 654). So supposedly were Sexburga, Withburga, and perhaps also Pandonia and Wendreda, all virgins, princesses and abbesses, whose gilds crop up very occasionally in wills. ${ }^{58}$ So did Edward king and martyr in St Edward's church in Cambridge (but not St Edmund) and

54 Raine, Fabric Rolls, 274-306; R.B. Dobson, "The Foundation of Perpetual Chantries by the Citizens of Medieval York," in his Church and Society in the Medieval North of England (London, 1996), pp. 253-84; see also Dobson, "The Later Middle Ages," in A History of York Minster, ed. G.E. Aylmer and Reginald Cant (Oxford, 1977), pp. 44-109, at p. 95.

55 Marie-Hélène Rousseau, Saving the Souls of Medieval London: Perpetual Chantries at St Paul's Cathedral, c. 1200-1548 (Farnham, 2011), p. 4, and Appendix; Thacker, "Cult of Saints," p. 121; see also Rosalind Hill, "A Chaunterie for Soules': London Chantries in the Reign of Richard II," in The Reign of Richard II: Essays in Honour of May McKisack, ed. F.R.H. Du Boulay and Caroline M. Barron (London, 1971), pp. 242-55.

56 A. Hamilton Thompson, "The Statutes of the Collegiate Church of St. Mary and All Saints, Fotheringhay," Archaeological Journal 75 (1918), 241-309, at p. 296.

57 Bainbridge, Gilds in the Medieval Countryside, pp. 61-64.

$5^{8}$ Bainbridge, Gilds, p. 62. 
Archbishop Æthelnoth (d. 1038).59 The same pattern occurred In Norfolk and Yorkshire, where fewer returns survive from 1389 and vastly more wills. In Yorkshire, "a few gilds were dedicated to local saints" or pre conquest saints, to SS Hilda, John of Beverley, Botolph, Wilfrid, and Ninian, but what was most striking was the absence as patrons of SS Cuthbert, Oswald, and William of York. ${ }^{60}$ A score of native dedications occur in Norfolk to Botolph, Edmund, Edward, Ethelrelda, and Withburga ${ }^{61}$ Native dedications were extremely local, Æthelrelda in Ely, John in Beverley, Wendreda in March, and Wilfrid in Ripon, and only there. Almost all Norfolk saints occurred in churches with the same dedication, seven gilds of St Botolph (out of nine) in churches of St Botolph, testimony to the survival of the cult where originally rooted, but not to a more widespread or more enduring movement.

The foundation of new colleges was an opportunity for new dedications, perhaps to Anglo-Saxon saints but generally to others. The original dedication of the church or chapel that normally preceded them is sometimes lost. When parish churches or castle chapels were erected into colleges, it was common to expand the patronage - at Ottery St Mary (Devon) in 1337 to Christ, St Mary, and St Edward the Confessor and All Saints and at Tonge (Staffs.) in 1410 from St Bartholomew to God, Our Lady, and St Bartholomew. Edward III similarly extended the patronage of his much enhanced college at Windsor from St Edward the Confessor to Our Lady, St George, and St Edward, henceforth known as St George's for short. In all these instances the original patron was retained, which was not always the case: at Fotheringhay (Northants) St Edward the Confessor disappeared between 1398 and 1410 and at Windsor and Battlefield (Salop.) colleges SS George and Mary Magdalene obscured their co-patrons in common parlance. ${ }^{62}$ Retention of the dedication need not imply any relevant observances. There may or may not be altars with this dedication and the services prescribed in surviving collegiate statutes almost never mentioned them. The two or three masses per day were invariably in honour of the Virgin, the

59 Bainbridge, Gilds, pp. 62-64; see also Ridyard, "Condigna Veneratio," p. 180. To my knowledge, neither Pandonia nor Wendreda are discussed in Yorke's work.

6 David J.F. Crouch, Piety, Fraternity and Power. Religious Guilds in Late Medieval Yorkshire, 1389-1547 (York, 2000), pp. 102 and 252-59.

61 Farnhill, Guilds, pp. 176-208.

62 Dugdale, Monasticon, 6, passim. Modern studies of colleges say little about the dedications, e.g. Nigel Saul, Death, Art and Memory in Medieval England: The Cobham Family and their Monuments 1300-1500 (Oxford, 2001); The English Medieval College and its Context, ed. Clive Burgess and Martin Heale (Woodbridge, 2008), pp. 21-22; Mark Bailey, "Sir John de Wingfield and the Foundation of Wingfield College," in Wingfield College and its Patrons: Piety and Prestige in Medieval Suffolk, ed. Peter Bloore and Edward Martin (Woodbridge, 2015), pp. 31-48, at pp. 45-46. 
Sarum mass of the day, or for the souls of founders and benefactors: the votive masses operated to a strict rota that never, for instance, specified SS Edward, George, or Mary Magdalen.

A particularly striking example was the shortlived college that Richard Duke of Gloucester, the future Richard III, established at Middleham in Yorkshire in the parish church of the gth-century virgin martyr St Alkilda. Alkilda remained as third patron, after Jesus and Our Lady, but received no particular devotions. His second even more abortive college at Barnard Castle relegated the original patron Margaret of Antioch to fourth place behind Jesus, the Virgin, and Ninian. His third college at York Minster was dedicated to God, the Blessed Virgin, George and Ninian. ${ }^{63}$ Middleham's seven priests took the names of patron saints: only the Virgin was scriptural, four were traditional (Anthony, Barbara, George, Katherine), and two-Cuthbert and Ninian - were northern and preConquest in origin. The feasts of Cuthbert in Lent and Ninian on 16 September were elevated to principal feasts, comparable to Christmas and Easter. The duke named no less than 43 favourite saints: some scriptural, most from antiquity, no less than eleven virgins, but also including the two northern saints Wilfrid of Ripon and William of York. Some of these were Sarum feasts, only a couple York feasts, another couple were neither. That all 43 were designated as double feasts, with particularly elaborate sung services not always available in the Sanctorale, must have imposed strains both in locating appropriate material and in performance on the clerical staff. St Ninian was foregrounded in all Richard's colleges. A devotion to St Ninian was added to the book of hours that Richard was using at his death. ${ }^{64}$

Whilst highly personal, such selections were not unusual in the century before the Reformation. Particular masses were commissioned on particular weekdays. Whatever the dedication of the chantry or altar, 13th-century and 14th-century founders had to make do with the services that the Church prescribed in the mother church, the masses of the day as modified by saints' festivals as prescribed by the relevant use, whether secular (eg Sarum) or monastic. For late foundations, those dating from the 15 th and 16 th centuries, the principle increasingly applied that founders prescribed their own preferences. Votive masses, as these were called, operated on a weekly rota: Trinity mass on Sunday, the Angels on Monday, Salvation of the People on Tuesday, the Holy

63 Dugdale, Monasticon, 6:1440-1; R.B. Dobson, "Richard III and the Church of York," in Kings and Nobles in the Later Middle Ages, ed. Ralph A. Griffiths and James Sherborne (Gloucester, 1986), pp. 130-54, at p. 145, Building works ceased and the endowments were resumed on the king's death.

64 Raine, Fabric Rolls, p. 305. All three colleges died with the king. 
Ghost on Wednesday, Corpus Christi on Thursday, Holy Cross on Friday, and the Virgin (principally the Annunciation on Saturday), to which were added such variants as the Requiem mass or on Fridays the Name of Jesus or Five Wounds of Christ. ${ }^{65}$ Some founders transposed the days, selected other masses that might well focus on Cuthbert or Ninian, and added prayers and anthems to particular saints.

\section{Postscript: Anglo-Saxon Saints after the Reformation}

Amongst the many thousand new dedications of post-Conquest England there were therefore significant numbers relating to native and pre-Conquest saints. All this however was changed at the Reformation, as the monasteries were swept away in 1536-40, colleges, chantries, guilds, fraternities, chapels, and many hospitals by Edward vi. Subsidiary altars became redundant. The cathedrals were retained, generally re-dedicated to the Trinity, and a few monastic and collegiate churches such as Malmesbury and Wimborne that became parish churches retained their ancient dedications to St Cuthburga and St Milburga. Only the parish churches remained of the post-Conquest foundations and up to 30 per cent of these dedications, Orme estimates, were changed. ${ }^{66}$ Anglo-Saxon dedications were a high proportion of what was left. They were: predominantly to saints from the bible and late antiquity, semi-legendary saints and virgin martyrs of west European tradition, but among them only a smattering of Anglo-Saxon and British saints. It was these and tiny numbers of post-Conquest saints that distinguish almost all the medieval churches that survive today. Over the next two centuries there were few new Anglican churches - it was virtually impossible to found new parishes - and hence few new dedications. Such dedications moreover ceased to matter much and seemed often to be forgotten. Whilst the Church of England recognized only certain saints, no effort was made to purge such legendary saints as Christopher and George or those of doubtful sanctity. The Puritans and dissenters, who disapproved of the cult of saints, did not dedicate their meeting houses. Meantime the population grew and shifted, to outer suburbs at London and into new spa towns (e.g. Bath), ports (e.g. Liverpool), and industrial towns (e.g. Manchester), and the demand for new parishes, new churches, and more sittings became irresistible. Parliament's response was to vote £1 million in 1818

65 Michael Hicks, “The Piety of Margaret Lady Hungerford (d. 1478)," Journal of Ecclesiastical History 20 (1987), 19-38, at p. 31.

66 Orme, Dedications, p. xii. 
and another $£ 500,000$ in 1824 towards new churches, almost all of which were dedicated to scriptural saints. The handful of exceptions, all outside London, included St Cuthbert in the North and St David and St Fagan in Wales. ${ }^{67}$ The host of Gothic Revival churches that followed in the 19th and early 2oth centuries were a little more wide-ranging: St Aidan, St Augustine, and St Edward the Confessor featured occasionally. The revived Roman Catholic church recognized not only pre-Conquest but also post-Reformation saints, such as St Thomas More and St John Payne. The University of Winchester, a 19th-century Anglican foundation named for a period after King Alfred in 1928, dedicated halls of residence and teaching blocks at various times to SS Alphege, Edburga, Grimbald, and Swithun. The main site is still named after King Alfred.

\section{Leavings or Legacy?}

This survey has presumed that dedications mattered. One might reasonably ask why. Originally, admittedly, it was believed that patron saints interceded on behalf of parishioners, founders, benefactors with the Heavenly King. Right up to the Reformation pious Christians continued to seek the intercessions of these ancient saints and to make offerings and more permanent benefactions to them. Other types of pious expression, such as the depiction of saints on rood screens and vestments and dating conventions, suggest that Anglo-Saxon saints were rooted more firmly in English sentiment than the small number of new dedications suggest. What did the English know about these saints and how could they know it? Relatively few saints qualified for proper services, that specifically celebrated their lives and deaths, and the collections of saints' lives, notably the Golden Legend and Osbern Bokenham's Legends of Holy Women, treat hardly any of them. It is not likely that Anglo-Saxon vitae (of St Botolph, for instance) were widely read in the later Middle Ages. Intercession was continued, but less often, as many patrons became less esteemed and generally indeed lost their dedication feasts, as new saints, new liturgical feasts, and especially the Blessed Virgin rose in importance. Some Anglo-Saxon saints remained in the calendars, but they were rarely selected as patrons to the thousands of new churches, monasteries, chapels, gilds and chantries. Admittedly the cults of Cuthbert in the North, Edmund in East Anglia, and Swithun in Wessex did flourish. They have certainly lasted much better than the new saints of post-Conquest England whose devotions were effectively abolished

67 Arnold-Forster, Studies in Church Dedications, 1:11. Dobson, "Richard III and the Church of York," p. 145 . 
at the Reformation. The really lasting Anglo-Saxon legacy has been the implanting in England of those saints current in late antique Rome: it is they who colonised the churches of Anglo-Saxon England, outnumbering the native saints, many of whom were squeezed out at the Norman Conquest and the Reformation. There survive today thousands of pre-Conquest dedications, but only a fraction signal the impact of the Celtic saints, Anglo-Saxon, and Viking kings and bishops, and King Olaf. Much more numerous but also much less obvious are the dedications to scriptural and antique saints that today are a principal legacy of the Anglo-Saxon Church. 